\title{
Taiwanized "New Taiwanese": The Effect of Taiwanization on the 2008 Presidential Election Campaign of Ma Ying-jeou
}

\author{
In: Asia-Pacific Social Science Review, Vol. 9, No. 2 (2009) Manila, pp. 19-34
}

\author{
Malte Philipp Kaeding, Hong Kong Baptist University \\ mkaeding@sino.uni-heidelberg.de
}

\begin{abstract}
This article argues that the 2008 Presidential election campaign of the KMT candidate Ma Ying-jeou witnessed a shift in the identity content of the KMT concept of "New Taiwanese" from the civic side of the spectrum towards the ethnic side. In order to become electable, Ma Ying-jeou had to portray a very "Taiwanized" image. This suggests the strong impact of two decades of Taiwanization policies, focused on the ethnic and cultural realm, on the political market of Taiwan. The emergence of the "culturally enhanced" concept of "New Taiwanese" emphasizes the importance of cultural and ethnical discourses in national identity formation. After Ma's election, his stance towards China has lacerated once again the conflict of identities that will continue to shape the future of the islands.
\end{abstract}

\section{INTRODUCTION}

Taiwan identity has been the topic of scholarly interest since the country's transition to democracy (Wachmann, 1994). Research shows that the number of people identifying themselves identified as Taiwanese, or Taiwanese and Chinese, has been rising constantly over the past decade; while the number of those identifying themselves as Chinese has sharply fallen ${ }^{1}$ (Election Studies Center , 2007). National identity has become an election topic since the early days of democratization; and parties utilize the issue to mobilize voters and to position themselves. In 2008 the winner of the Presidential Elections was Chinese Nationalist Party (Kuomintang KMT 中國國民黨) candidate, Ma Ying-jeou (馬英九). Many commentators concluded that his election marked the end of identity politics in Taiwan and that it was not an issue during the campaign.

This article argues that, although the 2008 campaign apparently was dominated by economic issues and future relations with China, identity indeed played a key role. Ma Ying-jeou had to convince the Taiwanese voters that he would not sell out the country to China, and therefore made great efforts to demonstrate his "Taiwaneseness." His articulation of Taiwan identity in the campaign reflects two decades of Taiwanization ${ }^{2}$ policies in the Republic of China (ROC 中華民國). The

\footnotetext{
${ }^{1}$ According to data by the National Cheng-Chih University Taiwan, the number of people identifying themselves as Taiwanese has risen from $17.3 \%$ in 1992, to 43.7\% in 2007. While in 1992, $26.2 \%$ of Taiwan's people considered themselves to be Chinese, in 2007 it was a mere $6.5 \%$. The most frequent identity category is a combined Taiwanese/Chinese identity, chosen by $44.5 \%$ in 2007 (45.4\% in 1992) (Election Studies Center, National Cheng-Chi University Taiwan).

${ }^{2}$ The Chinese term used for Taiwanization is 本土化; this can also be translated as "nativization", "localization" or "indigenization". Yet Bruce Jacobs argues that these terms are not appropriate. "Localization" would convey the Chinese idea that Taiwan is only a "local" government.
} 
broad acceptance in the public of these policies, especially in the cultural area, and the dramatic increase of identification as Taiwanese, have framed the identity debate and the political market. Following the Downsian argument of parties as vote-maximizing entities (Downs, 1957), a move in the direction of the ideological center of Taiwan identity could be observed. ${ }^{3}$ The KMT has maneuvered towards fully embracing this Taiwan identity. Yet, the strong ethnic and cultural undertone of Taiwanization under the second Chen administration, together with $\mathrm{Ma}$ as a so-called mainlander candidate, posed a great challenge to the campaign. How could Ma Ying-jeou be perceived as truly Taiwanese while still appealing to other identities and ethnic groups? How would he formulate Taiwan identity and what components of it would the campaign emphasize? Which campaign instruments and strategies would be used to convey the Taiwanese image of the candidate? Essentially the campaign would involve steering to the ethnic realm of identity while upholding the civic-based "New Taiwanese" identity. This paper argues that as a solution to this potential campaign problem, the KMT employed the concept of a "culturally recharged" "New Taiwanese".

An exposition of theories of national identity construction will be given to provide the theoretical background for this study; to be followed by a short introduction into the development of Taiwan identity. Approaches to the analysis of this issue will likewise be given.

Examinations of different stages of Taiwanization policies underscore their evolution as well as their impact on past election campaigns. Findings gathered during a field trip to Taiwan during the elections provide detailed information on election strategies and instruments. Together with a content analysis of Ma Ying-jeou's election platform and an ethnographic study of campaign promotion material, all this will demonstrate the identity option of the KMT and present the main subject of this paper. Lastly, conclusions on the further development of Taiwanization and Taiwan identity are drawn.

\section{NATIONAL IDENTITY}

Debates have arisen on the origin of nations, nationalism and national identity shifts The essentialist or primordial view on national identity assumes that certain group identities and attachments are given, based on blood, race, language, territory. Clifford Geertz believes that primordial identities are natural and possess an "ineffable, and at times overpowering, coerciveness in and of themselves" (Geertz, 1973, p. 259), as essentially, these identities deal with sentiments or affection (Llobera, 2004, p. 185). Yet Geertz and other modern primordialist theorists agree with the relativistic notion that even as the primordial bonds are assumed, they are powerful because they are perceived to be real (Schubert, 2002, p. $57 \mathrm{ff}$ ).

On the other hand the constructivist approach to the study of nationalism and national identity sees the nation as an "imagined political community" (Anderson, 1983, p. 6). It stresses the invention and construction of a nation and refuses ethnic perennialism. Thus, by way of example, it accepts the possibility of a rediscovery of a nation (Ibid.). National identities hence develop not from something pre-existing in communities, but are based on "invented traditions" and symbols created by elite groups of a society.

\footnotetext{
"Indigenization" could refer to the aborigines, the indigenous population of Taiwan; and the term "nativization" is too vague (Jacobs, 2000, p.18).

${ }^{3}$ Dafydd Fell's seminal study on party change in Taiwan has shown how parties have moderated their polarized stances in response to public opinion and election results (Fell, 2005, p. 128).
} 
“ 'Invented tradition' is taken to mean a set of practices, .... of a ritual or symbolic nature, which seek to inculcate certain values and norms of behaviour by repetition, which automatically implies continuity with the past" (Hobsbawn, 1983, p. 1). Yet, only those traditions are successful which are "broadcast on a wavelength to which the public was already to tune in" (Ibid., p. 263).

Anthony D. Smith adopts a "middle-ground approach" (Cerulo, 1997, p. 390) as he creates a linkage between social constructivism and essentialist views when arguing that a nation possesses certain "fundamental features". These fundamental features can be found in his definition of a nation as a "named population sharing an historic territory, common myths and historic memories, a mass, public culture, a common economy and common legal rights and duties for all members" (Smith, 1991, p. 14). Central to his "ethno-symbolic approach" is the concept of an ethnic core or ethnic community, representing a dominant group of people, which is able to incorporate other "ethnics" to its created state via annexation or attraction (Ibid., p. 39). This indicates that national identity is at the same time a product of "ancient" ethnic identity as well as of deliberate manipulation through ideology, commemoration and symbolism $^{4}$ (Cerulo, 1997, p. 390). Through its relationship with the ethnic belonging of a human being, national identity hence represents the political form of an ethnic identity (Schubert, 2004, p. 536).

The most influential dichotomy in the understanding of national identity is that of Western/political/civic identity versus Eastern/ethnic/cultural identity. Anthony D. Smith gives an elaborate definition when he argues that the Western or civic model entails a historic territory, a legal-political community, legal-political equality of members, articulation in a set of rights and duties, as well as a common civic culture and ideology. On the other hand, the emphasis of the non-Western concept is on a community of birth and native culture (Smith, 1991, p. 11). According to Smith " $\mathrm{t}] \mathrm{he}$ nation is seen as a fictive 'super-family'.... Genealogy and presumed descent ties, popular mobilization, vernacular languages, customs and traditions: these are the elements of an alternative, ethnic conception of the nation ...." (Ibid., p. 12). However he also acknowledges that most states and nations contain both "civic and ethnic elements in varying degrees and different forms" (Ibid., p. 13). Nevertheless he believes that the civic/ethnic division "remains valid and useful" (Ibid., p. 81).

Stephen Shulman argues that civic identity can be understood as rationalistic and voluntary, its components ${ }^{5}$ being external to the individual; while cultural and ethnic components are internal. The direct connection to a person's physical and psychological structure by language, ancestry, race, traditions and religion hence accounts for the intense emotional attachment to ethnic national communities (Shulman, 2002, p. 580). This finding has direct consequences for state and party policies. State policies aimed at constructing a national identity could use symbolic and educational measures which stress the ethnic and cultural components of identity

\footnotetext{
${ }^{4}$ This concurs with John Hutchington's ideas of cultural nationalism. Although a modern phenomenon, he argues that its national symbols, memories and cultural practices chosen, aim at resurrecting or awakening existing historic memories of a community (Hutchinson, 1987, p. 20 ff).

5 Shulman's study on civic/ethnic nationalism and identity in Europe concludes that the strength of cultural components of national identity in Western European countries is based on the fact that civic components alone can not provide sufficient unity in a state (Shulman, 2002, p. 580.)
} 
in order to achieve a strong emotional attachment to the nation. Consequently political parties that seek electoral success would equally focus on the emotional area of identity components. Post-Cold War political developments in the former republics of the Soviet Union and the Balkans, as well as right-wing populist parties in West Europe, appear to support these conclusions. However, the theories mentioned provide little insight on the question of shifts from emphasizing one identity component to emphasizing another. Governments may maneuver from putting emphasis on civic to ethnic components (e.g. former Yugoslavia) or vice versa (postSecond World War Germany); and small political parties change their stance one way or the other. However, fundamental movements between these identity components by dominant catch-all parties seem to be rare. The case of former state-party KMT in Taiwan could illustrate such a shift, that of moving away from the ideal of a civicbased "New Taiwanese" identity, and moving toward an emphasis on ethnic components of Taiwan identity. An election campaign analysis would provide an understanding of the instruments and strategies involved, as well as the difficulties and the general feasibility of such a project.

\section{EVOLUTION OF TAIWAN IDENTITY}

The study of Taiwan national identity offers a prime example of the multi-faceted definitions of identities and the different approaches and concepts to explain or justify them.

The roots of Taiwan national identity are closely related to the history of the island. Colonized by the Dutch (1624-1661), Taiwan was a refuge for Ming Dynasty loyalist General Koxinga (鄭成功) from 1661-1683, before it was conquered by the Qing Empire in 1683. Han-Chinese colonizers began to settle down in the plains, while the mountains were controlled by Austronesians, who had arrived in Taiwan several thousand years earlier. Taiwan was ceded to the Japanese after the Sino-Japanese war in the Treaty of Shimoseki 1895. The colonizers treated the inhabitants of Taiwan largely as second-class citizens, yet rapid modernization and substantial improvements in living conditions initially laid grounds for a positive identification with the island (Chang, 2000, p. 55). After 1945 the administration of the island was handed to the Republic of China, and the arriving KMT troops were welcomed as liberators (Cabestan, 2005, p. $32 \mathrm{ff}$ ). However, the new administrator used Taiwan's wealth to rebuild the Chinese mainland; moreover, their rule was plagued with incompetence, corruption and distrust of the former Japanese citizens (Philips, 2007, p. 282).

On February 28, 1947 the looming conflict between the KMT government and the Taiwanese resulted in an uprising. The regime brutally retaliated and the crackdown eliminated or silenced most of Taiwan's intellectual elite. This "February 28 Incident" (二二八事件) marked the affirmation of a unique Taiwanese identity and created a demand for autonomy and democracy (Chu and Lin, 2001, p. 123). After the KMT lost the Civil War in China, Chiang Kai-shek (將中正) retreated to Taiwan, together with approximately 1.5 million people from the administrative, army and business sectors.

With the support of the USA for the strategically important island, Taiwan was developed by the KMT into a "model province" for China, making rapid economic progress over the next decades. At the same time however a sub-ethnic cleavage emerged, between those newly arrived from the Chinese mainland and the Taiwanese 
- Han-Chinese who had been living in Taiwan for several centuries before $1945 .{ }^{6}$ For several decades the Taiwanese were completely excluded from political participation and power in the higher levels of institutions. Local culture and language ${ }^{7}$ were suppressed, as the KMT propagated its official "great China" nationalism (Schubert, 1999, p. 54), Taiwan was a natural part of the Chinese nation, the latter primarily defined in ethnical and cultural terms. ${ }^{8}$ When Chiang Ching-kuo (蔣經國), son of Chiang Kai-shek, became prime minister in 1972, he began the Taiwanization of the administration and cautious political liberalization (Cabestan, 2005, p. 35). Taiwanese national identity became more prominent and was expressed in literately circles like the Taiwanization movement (本土運動) and in native (鄉土) literature, both closely linked to the established political opposition, which called for democracy and participation (Hsiau, 2000, p. 91).

\section{DISCOURSES OF TAIWAN NATIONALISM}

Schubert (1999) divides the discussion on Taiwanese identity into three basic discourses:

The discourse of Taiwanese ethno-cultural nationalism argues that Taiwan identity is based on specific historic experiences and perceived cultural differences of the Taiwan people. The colonial past of the island - especially the Japanese rule - and its long separation from the Chinese mainland, are emphasized; these set it apart from Chinese nationalism and created a unique community sharing a common fate under the permanent threat of an antagonist China (Schubert 1999, p. 55).

Taiwanese culture is envisioned as a mixture of Western, Chinese and Austronesian influences. It is further argued that Taiwanese are ethnically different from HanChinese on the mainland. Centuries of inter-marriages between Chinese and aborigines resulted in a unique genetic make-up (Hsueh et al., 2005, p. 84 ff.). This ethnic and culture-based identity is fused with the memory of the suffering of the Taiwanese under the KMT's rule; it creates a powerful narrative of a Taiwanese identity that excludes the mainlanders.

In the discourse of the multi-ethnic nationalism approach, the Taiwanese nation is conceptualized as a harmonious, democratic and tolerant nation composed of four ethnic groups: mainlanders, Hoklo, Hakka, and aborigines. The concept considers ethnicity as an essential part of human identity formation, even as it asserts its fluidity (Schubert, 1999, p. 59). It thus departs from pure perennialism and invites ideas of constructivism. Some advocates of this approach aim at achieving a trans-ethnic

\footnotetext{
${ }^{6}$ Taiwanese (本省人 or 本地人) represent close to $87 \%$ of the population, mainlanders (外省 人) about $12 \%$. Taiwanese include people from southern Fujian (福建), Minan and Hoklo (閩南 and 福 佬) which make up approximately 77\%; and Hakka (客家) from southern Guandong (關東), representing roughly $10 \%$ of the population. The mainlanders are the immigrants who arrived in Taiwan after 1945 and their descendents (Ho and Liu, 2003, p. 155 ff.). Currently about 400.000 Taiwanese aborigines (原住民) have resituated in Taiwan, the only group of non-Han ethnic origin; they account for $2 \%$ of the total population and can be divided into several distinct ethnic groups themselves (Allio, 2000, p. 46).

${ }^{7}$ Taiwanese is a variant of the Minan (閩南) dialect, commonly referred to as Taiyu (台語).

${ }^{8}$ In this aspect, not only the Chinese nationalisms of the Communist party in China and the Nationalist Party on Taiwan, but also the radical ethno-cultural Taiwan nationalism have much in common. For a more detailed analysis of Chinese nationalism see Hughes (2006).
} 
identity, based on citizenship and memory of a common history, hence leading towards the idea of a civic nationalism (Schubert, 2004, p. 30).

According to the discourse of political or state nationalism, the foundation of a Taiwan nation is in line with the institutions of a liberal state. Therefore people might still define themselves as culturally or ethnically Chinese. This however, has no implications on the relationship with China or on the question of political unification (Schubert, 1999, p. 63). This idea of civic nationalism is very prominent in the academic community; it views the rise of Taiwan identity as it is directly connected to its geographical and political separation from China and subsequent democratic development (Cabestan, 2005; Liu, 2002; Schubert, 2004). Ernest Gellner states that as a political principle, nationalism always aims at achieving a harmony of nation and state entity (Gellner, 1983, p. 1). Schubert argues that this nation-state "figures as the institutional fulfillment of a community's quest for national identity", which leads him to the observation that "Taiwanese national identity must be regarded . . . as state identity" (Schubert, 2004, p. 536 ff.).

These three types of discourse on Taiwan identity had different impacts on the policies of the Taiwan government since the 1970s. As the issue of Taiwan identity is at the center of Taiwanization, the content of these policies reflects the visions of Taiwan nationalism of the governments in power.

\section{POLICIES OF TAIWANIZATION}

The issues of Taiwanese nationalism and Taiwanese identity have been part of Taiwan politics since the 1970s. The visions of governments on this are varied, but the essential ideas propagated through their policies have remained the same. Taiwanization can be understood as a two-layered Taiwan-centered approach to politics; it aims at achieving political and cultural equality of Taiwanese, domestically vis-à-vis the ruling mainlanders, and the KMT brand of Chinese nationalism. Internationally it seeks to raise the prominence of Taiwan and to increase its international maneuvering space in opposition to the People's Republic of China.

Taiwanization was instrumental in creating a Taiwan identity with civic and ethnic elements. Policy measures undertaken to achieve this can be divided into:

1. The political realm - measures that include: the democratization of Taiwan's institutions; the push for membership in international organizations; and the strengthening of the country's sovereignty in opposition to China (civic identity);

2. The cultural realm - measures that raise the prominence of Taiwanese culture, history and languages; while at the same time reducing the symbolism of KMT Chinese nationalism (ethnic identity);

The reforms undertaken by Chiang Ching-kuo in the early 1970s were a reaction to the consequent international isolation after the ROC lost its UN membership. This undermined the domestic legitimization of the KMT's ideology of the ROC representing the whole China. Therefore measures included opening the party and administration to younger and able Taiwanese, and focusing more on local culture. In 1981 the Council for Cultural Affairs (文化建設委員會) was set up to promote 
Taiwan's cultural development (Chang, 2006, p. 189). However these first steps towards Taiwanization were tools aimed at securing the dominance of the KMT rule.

Chiang Ching-kuo's successor, the Taiwanese Lee Teng-hui (李登煇), introduced political changes that began democratization and, through majority rule, Taiwanization. In 1991 the first free national elections in Taiwan for the National Assembly and in 1992, the Legislative Yuan elections both resulted in very good results for the KMT, strengthening Lee's Mainstream Faction in the party. ${ }^{9}$ This consisted mostly, of Taiwanese and younger, more democratic and liberal-minded mainlanders; while the Anti-Mainstream Faction was supported by the older, conservative mainlander elite.

In this process of democratization the old mainland elite of the KMT was continuously weakened, while Lee consolidated his position (Tsai, 2005, p. 188). A more open discussion of the national question was one result (Jacobs, 2000, p. 36). The transition process came to a successful ending with Lee Teng-hui's victory in the first direct Presidential election in $1996 .{ }^{10}$ Lee continued his domestic reforms; at the same time he pursued a foreign policy (flexible diplomacy) designed to raise Taiwan's international status (Tsai, 2005, p. 194), thus moving away from the OneChina principle. ${ }^{11}$ The result of Taiwanization in the political sphere was the increasing identification of Taiwanese people with the state and its institutions.

The cultural Taiwanization further enhanced this feeling of belonging to Taiwan. The state underwent a transformation from a "cultural agent of Chinese nationalism to a powerful agent of Taiwanese identity" (Chu, 2004, p. 499). The government began to set up research institutes and museums on the island's culture and history, and to support native literature and the performing arts, without fully abandoning its Chinacentered position (Chang, 2004, p. 40). An important step in Taiwanization was taken in 1997, with the new junior high school curriculum “Getting to Know Taiwan” (認識 臺灣), which focused on the distinctive nature of Taiwan history, geography and society and gave "an impulse to the notion of pluralistic national identity and national identification" (Corcuff, 2002, p.160).

With Taiwanization, the KMT reacted to opposition pressure, hijacked the discourse and stayed in power, while Lee Teng-hui himself strengthened his position. As a Taiwanese, Lee wanted to break with the country's authoritarian past and converted transcend the old Republic of China into the ROC on Taiwan; he publicly apologized for the crimes of the KMT, (e.g. the February 28 Incident). Together with democratic practice, it led the way to a possible political re-socialization of the Taiwanese (Chao and Dickson, 2002, p. 5). Lee promoted the concept of the "New Taiwanese". It had

\footnotetext{
${ }^{9}$ In the first free parliamentary election in Taiwan, the KMT gained $64 \%$ of the seats; while the opposition DPP got $31 \%$. At the same time the ratio of mainlanders in the legislature dropped from $60 \%$ down to $22 \%$ after the election (Nathan, 1993, p. 435 ff).

${ }^{10}$ Lee Teng-hui won this election with $54 \%$ of the votes; while the DPP candidate Peng Mingmin received 33\% (Hsieh and Niou, 1996, p. 545).

${ }^{11}$ Examples were the 1995 travel to his alma mater Cornell University in the USA (Ibid., p. 197); and the 1999 so-called "special state-to-state" relationship between Taiwan and China. The foreign policy responded to a hostile China, particularly after Peking's heartless response to the 1994 murder of many Taiwanese tourists in China, and the 1996 missile tests in the Taiwan Strait by the mainland (Jacobs, 2000, p. 36).
} 
appeared as a slogan of the opposition Democratic Progressive Party (DPP 民進黨) in 1992, calling for ethnic harmony (Fell, 2005, p. 114); and it was later used by KMT candidate James Soong (宋楚瑜) when he ran for governor of Taiwan province in 1995 (Wong, 2004, p. 50). It was widely recognized when Lee used it to support Ma Ying-jeou in the 1998 Taipei mayoral race. ${ }^{12}$ The concept promoted a civic Taiwanese identity and focused on the unity of all people living on the island, on inclusiveness, consensus and identification with Taiwan and its future. ${ }^{13}$ People's ethnic background or time of arrival did not matter, as everybody shared the experience of living in Taiwan and was committed to it (Bedford and Hwang, 2006, p. $83)$.

In 2000, DPP candidate Chen Shui-bian (陳水扁) won the presidential elections, campaigning on the strength of his ethnic background as a Taiwanese. Taiwanization entered the next stage. In the international arena Chen could gain early success with the country's accession into the WTO next to China in 2001. Further efforts to widen Taiwan's international presence (i.e. bids for WHO and UN membership) were, however, met with strong opposition by the PRC. The policy towards China under Chen's presidency could be best described as inconstant, ranging from good will gestures and proposals for closer economic cooperation ${ }^{14}$ to the "one country on each side" (一邊一國) statement of 2002 (Schubert, 2007, p. 10). In the domestic realm Chen implemented further democratic reforms, established a referendum law, and continued breaking the links of state and military institutions to the KMT.

The more obvious changes, however, were made in the cultural sphere. As the mayor of Taipei, Chen had overseen important symbolic Taiwanization policies, such as the removal of Chiang Kai-shek statues and portraits, the renaming of the Chieh-shou Road (介壽路) ${ }^{15}$, and the opening of a museum devoted to the 228 Incident (Liu et al., 2005, p. 106).

This "spiritual homeland" was constructed by promoting tourism in Taiwan, Taiwanese literature and the new academic discipline of "Taiwan studies". In 2001 the compulsory subject "Native Language" (鄉土語言) was introduced in elementary schools; and a new high school curriculum was introduced, which prioritized Taiwan history over that of China and world history.

${ }^{12}$ Corcuff describes the event at the rally as follows: "Lee Teng-hui asked in Taiwanese, 'Ma Ying-jeou, where do you come from?' Ma replied, 'I am a new Taiwanese, who grew up drinking Taiwan water and eating Taiwan rice, a true Taipei man born in Wanhua District' " (Corcuff, 2002, p.187).

${ }^{13}$ According to Fell, Lee Teng-hui described the concept of New Taiwanese in these terms: "No matter if you came 400 or 500 years ago, or 40 or 50 years ago from the mainland, or if an aboriginal, we are all Taiwanese, so long as we all work hard for Taiwan and the ROC, then we are New Taiwanese” (不論是四, 五百年前來的, 或是四十年, 五十年前從大陸來的, 或是原住民, 攏是 咱們台灣人，爲台灣，為中華民國在這裡打平，就是新台灣人.) (United Daily News, 3 December 1998, p. 5, quoted in Fell, 2005, p. 114).

${ }^{14}$ For example the establishment of the "three mini-links" direct connections to China from Kinmen (金門) and Matsu (馬組); and direct flights to the Chinese mainland for Taiwanese businessmen during Chinese New Year (Ibid., p. 8).

${ }^{15}$ Chieh-shou Road (介壽路) was changed into Ketagalan Boulevard (凱達格蘭大道). "Chieh-shou" literary means "Long live Chiang Kai-shek"; while "Ketagalan" refers to the Taiwanese aborigines originally living in the capitals area (Pan, 2000, p. 86). 
Symbolic changes were also undertaken, such as adding the English word "TAIWAN" to the cover of all Taiwanese passports in 2003 (Chang, 2004, p. $41 \mathrm{ff}$.). These changes accelerated in the last two years of Chen's term. The administration began a wide campaign of renaming public places, state-owned companies and buildings, replacing "China" with "Taiwan". Prominent examples were the change from "Chinese Petroleum Corp. (中國石油)” to “CPC Corp., Taiwan (台灣中油)”; and from “Chunghwa Post (中華郵政)" to “Taiwan Post (臺灣郵政)” in 2007 (Shan et al., 2007, p. 1). In September 2006 Chiang Kai-shek International Airport (中正國 際機場) was renamed “Taiwan Taoyuan International Airport (臺灣桃園國際機 場)“ (Executive Yuan announcement, 2006).

The name changes were met with opposition not only by the KMT, but also by some of the employees of these companies. The name change of the Chiang Kai-shek Memorial Hall (國立中正紀念堂) into “Taiwan Democracy Memorial Hall (台灣民 主紀念館)” received the most attention (Li, 2007, p. A15).

Comparing the cultural policies of the KMT with that of the DPP, one can note that the former was still linked to its Chinese roots; while the latter focused solely on Taiwanese-ness and tried "to create a new spiritual homeland" (Chang, 2004, p. 39; Chang, 2006, p. 202). The rapid and forceful Taiwanization under Chen Shui-bian could be described as a process of De-Sinization, as cultural and symbolic ties to China and Chinese nationalism of the authoritarian era were cut and replaced by Taiwan centrism (Chang, 2004, p. 44). Theoretically the primarily civic concept of "New Taiwanese" was still rooted in all three basic discourses of Taiwanese identity; it contained elements of ethno-cultural (e.g. common history), multi-ethnic to state nationalism (e.g. democratic values and system). Under the Chen administration the ethno-cultural discourse dominated, marking a shift towards an emphasis on the ethnic content of Taiwan identity.

\section{TAIWANIZATION IN ELECTION CAMPAIGNS}

In Taiwan elections the identity question has played a crucial role as parties use this issue to position themselves and attract votes. From the time of the Taiwanization policies of Lee Teng-hui and later, of Chen Shui-bian, a Taiwan centered consciousness and a Taiwan identity has become a mainstream consensus. The DPP appeals to just one identity; the KMT on the other hand, as a catch-all party, must constantly maneuver between its mainlander and Taiwanese constituencies. It takes a center position with regard to the identity question. After the departure of Lee Tenghui in 2000, the KMT adjusted its position several times. Under the chairmanship of Lien Chan (蓮戰) (2000-2005) the party initially returned to ROC Chinese nationalism, which was dropped during Lee Teng-hui' s second term. In 2000 the national flag and other national symbols were heavily used to attract traditional KMT supporters (Fell, 2005, p. 115).

Having said that, Taiwan nationalism has also become an increasingly important issue in campaigns. This can be seen with Lien who used it in 2000 to attack his rival James Soong, who was born in China to Chinese parents, for not being a true Taiwanese. (Bedford and Hwang, 2006, p. 100). Trends towards Taiwanese nationalism became stronger after the defeat of the KMT in 2000. The party then combined Chinese and Taiwan identity symbols and imagery, thus appealing to the double identity of many voters and promoting ethnic reconciliation (Fell, 2006, p. 30; Fell, 2007, p. 28). It 
largely adhered to the "New Taiwanese" principles. Taiwanization of the KMT became apparent in the 2004 presidential elections, where a stronger emphasis was placed on ethnic Taiwan identity. Lien Chan and his vice-presidential candidate James Soong were both regarded as mainlanders. They put great emphasis on their Taiwan identity and tried to show their love for Taiwan. ${ }^{16}$ Despite all of the KMT's efforts to embrace Taiwanization, the party still lost by a narrow margin. Many voters did not believe the Taiwanese image projected by Lien and Soong, as they were still regarded as parts of the old mainland elite of the party.

\section{MA YING JEOU'S PRESIDENTIAL CAMPAIGN}

The 2008 Presidential election was held two months after the KMT had won a substantial victory by securing a three-fourth majority in the legislature. The results reflected a general dissatisfaction with the DPP government, particularly with the perceived dire state of the economy ${ }^{17}$ and a series of corruption scandals that involved high-ranking DPP officials and the circle surrounding the President.

In light of this pre-election situation, Ma was considered to be the favorite against the DPP candidate, the former Kaohsiung mayor and premier Hsieh Chang-ting (謝長廷). Ma was very popular and the media was exceptionally friendly to him. During his time as a minister of justice and Taipei mayor, he had managed to build up the image of a modest, hard-working and "clean" politician. Uncertainty, however, remained regarding the issue of his identity. In the past two elections this had been decisive for the victory of the DPP. He was born to mainland Chinese parents in Hong Kong and had held important political positions during the authoritarian era, issues raised by the DPP campaign which questioned his loyalty to Taiwan. ${ }^{18}$ An important aim of his campaign was therefore to portray himself and the party he represented as truly Taiwanese, focusing on the well-being of the country and defending its sovereignty. In general the campaign platform tried to strike a balance between Taiwan-centered consciousness and the Chinese identity of the party. This was particularly challenging, as he vigorously promoted improvement of cross-strait relations, identifying China as the key to Taiwan's economic recovery. Ma tried to assure voters of his commitment to the sovereignty of Taiwan ${ }^{19}$, with the "three no's" formula (no unification, no independence, no armed conflict) regarding relations with China (Rigger, 2008, p. 692). In light of the difficulties Ma was facing regarding his own and the party's identity and the interests of the nation, the concept of "New Taiwanese" was a means of amalgamating these diverging interests. The election campaign showed the adaptation of the concept through strategies and instruments.

\footnotetext{
${ }^{16}$ One of the most famous events of the 2004 election saw Lien and his wife, together with the KMT secretary general, kneeling down and kissing the ground (Wong, 2004, p. 50), gestures repeated by Soong and his wife. The event was then marketed in the election advertisements of the KMT.

${ }^{17}$ The economic indicators were, comparatively speaking, good, with 5.7 percent growth and 3.9 percent unemployment in 2007; but the middle class had experienced long-term wage stagnation and reduced purchasing power (Muyard, 2008, p. 82).

${ }^{18}$ The DPP claimed that Ma possessed a valid US green card and that his two daughters possessed US passports (Bruyas, 2008, p. 1).

${ }^{19}$ Ma further underlined his firm position vis-à-vis China when he strongly condemned the Chinese crackdown in Tibet in March 2008. In his statement he even considered a boycott of the 2008 Peking Olympic Games (Ma Statement, 2008).
} 


\section{Election Platform}

At the center of Ma's election platform was the economy, i.e. how Taiwan's international status should be raised to that of being an international economic centre in the Asia-Pacific region. The key element of his proposals were the so-called "633 objectives," raising annual economic growth to $6 \%$, raising per capita GDP to at least US\$ 30,000, and reducing the unemployment rate to less than 3\% (Ma Platform Presentation, 2008).

In order to achieve these ambitious goals, he emphasized the importance of closer relations and increased interaction with China, through direct transportation links, so as to allow great numbers of Chinese tourists into Taiwan and the so-called "crossStrait common market” (兩岸共同經濟基金). Taiwan was heralded as a role model for democratic development; but democracy under Chen Shui-bian had become a mere pro forma electoral democracy, unjust, corrupt and disrespectful of constitutionalism (Ma and Siew, 2008b). Ma promised new governance ethics and an end to corruption. He emphasized the rights of different ethnic groups (e.g. Hakka, Hoklo), and proposed a variety of measures to help the aborigines, promising more financial support and the protection of their traditions. In his platform Ma Ying-jeou portrayed himself and the party as true protectors of a free, democratic and multiethnic Taiwan (Ma and Siew, 2008a).

Through proposals on culture policy, the KMT's balancing act between its Chinese heritage and the Taiwanized reality became obvious, promoting Taiwanese culture, while at the same time stressing the islands Chineseness. He pledged to spend more money on cultural projects and Taiwanese arts and science, to create new domestic and international brands, and to set-up various cultural centers and foundations (e.g. Taiwan Film Center, Taiwanese Public Broadcasting Center). Taiwan's Chinese culture was highlighted in his dream of a Taiwanese Nobel Prize for the Chinese world (華人世界). According to Ma Ying-jeou, Taiwan's culture is a bridge for better cross-strait relations. Culture instead of politics should play the main role. Through knowledge and academic exchange people on both sides could develop mutual trust and respect. Limitations for investments and tourism from the mainland should be reduced. Cultural and artistic exchange across the Strait was to be intensified and a dictionary in traditional and simplified Chinese characters, to be created, facilitating communication between Taiwan and China (Ma and Siew, 2008c).

\section{Election Strategy}

The experience and capabilities of the KMT in the economic area was the main theme of the campaign. It was accompanied by a call for change in government and an end to corruption. The Nationalist Party portrayed itself as a party of all Taiwan people, using the concept of "New Taiwanese". In the 2008 KMT campaign negative campaigning was largely absent. This marked a stark contrast to the 2004 campaign in which personal attacks on Chen Shui-bian had reached worrisome dimensions (Schafferer 2006, p. 49). The campaign used a wide range of methods to communicate its message, ranging from billboards, posters and banners, campaign bills, leaflets and brochures to newspaper and television advertisement.

\section{Campaign Advertisement}

Designs on public campaign advertisements were very specialized; posters, billboards, banners or advertisement on busses and taxis included often relevant (economic) messages for specific geographic areas. In Pingtung county (屏東縣) billboards gave detailed information on the advantages to farmers of the "cross-Strait common 
market $^{20}$ ”. In Taichung city (台中市) infrastructure projects were promised ${ }^{21}$; and in Kaohsiung city (高雄市) the local airport would benefit from direct links to China. ${ }^{22}$ The "New Taiwanese" image of the party and its position between the poles of Taiwanization and ROC heritage were encapsulated in a banner at the Taipei KMT campaign headquarters. Covering thirteen storeys, the banner showed Ma and his vice-presidential candidate Vincent Siew (蕭萬長) standing above a crowd of women and children from all walks of life, with three aborigines prominently positioned next to the candidates. Above the candidates were the blue sky and the campaign slogan of the KMT “Taiwan moves forward - Taiwan must win” (台灣向前行 台灣一定贏). To the left of the banner, there was a ROC flag. ${ }^{23}$

\section{Newspapers and Campaign Material}

Newspaper advertisements focused on linking Hsieh Chang-ting to the unpopular Chen administration, the corruption of the DPP, as well as to economic issues and promised change. In campaign literature and promotion material, similar topics dominated. However there was one other important theme - identity. Ma assumed roles at both ends of the spectrum of a New Taiwanese identity. He was frequently portrayed in traditional aborigine outfit and as a true friend of their culture and their cause, demonstrated by names some tribes had given in their native language. He was also shown as a sportive, young, modern and international leader. In a leaflet he appeared together with several young professionals in their thirties, such as Internet entrepreneurs or the US-born Taiwanese singer Wang Lee-Hom (王力宏). A postcard for Chinese New Year pictured him running next to a tiger, symbolizing his strength and also his year of birth according to the Chinese zodiac. The design of the postcard included various references to traditional Chinese culture and the Republic of China, with its blue colors referencing the blue part of the ROC flag and the Presidential Palace as a backdrop. In the KMT Taipei campaign headquarters, a set of four postcards was distributed that showed only the ROC flag and the signature "I love ROC", the reverse side featured scenes from the Chiang Ching-kuo era.

\section{Campaign Rallies}

The identity issue and the goal of the KMT to cater to the entire range of voters became evident in various campaign rallies and events. The Nationalist Party presented itself as a truly Taiwanese party, yet ROC symbols like the national flag, were omnipresent. The style and progression of rallies had adopted many ingredients of past DPP rallies (Schafferer, 2006, p. 50). To create a passionate experience for the participants and stir up emotions, songs were sung, dances and other acts performed. In the south of Taiwan the events were held mostly in Taiwanese (less than 20 percent of the announcements were made in Mandarin); while in the north a more equal mixture of Mandarin and Taiwanese was used. In Kaohsiung City the central campaign rally a week before the election included songs and dances by aborigine

${ }^{20}$ Billboard at motorway near Neipu (内鋪), Pingtung county. (The author's observation on March 17, 2008).

\footnotetext{
${ }^{21}$ Billboard next to Taichung central station. (The author's observation on March 18, 2008).

${ }^{22}$ Billboard on Wu-Fu Road (五福路). (The author's observation on March 16, 2008).

${ }^{23}$ The author's observation on March 20, 2008.
} 
groups. ${ }^{24}$ During a rally in Taoyuan City (桃園市) a day before the election, Mandarin and Taiwanese songs were performed ${ }^{25}$ and at the central event of the Overseas Chinese, in Taipei (台北市), the national anthem and national flag anthem were sung, followed by other classic Chinese songs. ${ }^{26}$

\section{Television Advertisement}

The double identity of the KMT was less apparent in television advertisements. Clips either promoted Ma's economic proposals or called for a change of government. The only identity promoted was the Taiwanese identity of the candidate. Even in commercials with economic content, signs of Taiwanization were clearly visible. These signs were the use of all three major languages, Taiwanese, Mandarin, and Hakka; and frequent reference to the landscape of Taiwan and important scenic spots that conveyed a feeling of belonging to the island.

One of the most prominent examples of these "Taiwanized" spots was "The strength to change" (改變的力量). The spot featured KMT county heads and city mayors reporting for duty and stating that they were prepared, and that the time was ready for change; they spoke in all three languages. The clip showed images of running horses on a beach at dawn, Taiwanese landscape, important places and structures. On the whole, it evoked a feeling of readiness while closely linking the party to Taiwan and its development.

Music was an important element in a clip on social policies. It showed Ma Ying-jeou jogging with others, while featuring two lines from the Taiwanese song "Move forward" (向前走) by Liem Giong (林強), one of the most famous Taiwanese singers. The lyrics of this classic song from the early 1990s were "[Whatever comes don't be surprised] I fear nothing”啥物攏不驚 and “[Move forward] Keep running” (向前走). The television advertisement "Our Taiwan - our home” (咱的台灣 咱的家) was a model case of Taiwanization and the catch-all "New Taiwanese" identity promoted by Ma during the 2008 election campaign. The video featured two classic clusters of images associated with Taiwan as a homeland. The islands landscape, in this case the Taiwan Mountains with tree trunks on green hills surrounded by clouds; and the small country village with children playing and people happily working in natural surroundings, drinking tea. In the clip, several famous Taiwanese and Chinese food was shown, like the famous Chinese pink wedding cakes. The variety of the islands culture was demonstrated by featuring Chinese opera, as well as aboriginal traditions and various temples. A group of young people was shown sitting happily together, talking and drinking tea, representing different ethnic groups. Ma Ying-jeou casually ran towards the group, joined them and together they wrote a Chinese New Year banner which included the phrase "All come together" (大家做伙來). The song ended with the slogan "Work together for a new Taiwan” (攜手同心奔向新台灣). The image of unity and harmony was further enhanced by the song accompanying the video. The "Happy reunion song” (歡聚歌) by the band New Formosa (新寶島康樂 隊) is a classic song from the 1990s, which is sung in three languages, Taiwanese, Hakka and an aboriginal language. Its lyrics state that ethnic backgrounds do not

\footnotetext{
24 The author's observation on March 16, 2008.

${ }^{25}$ The author's observation on March 20, 2008.

${ }^{26}$ All songs were performed by famous Taiwanese singers. (The author's observation on
} March 20, 2008). 
matter and people should be happy together and not divided. This advertisement clearly demonstrated the quintessence of Ma's "New Taiwanese" identity.

Ma Ying-jeou's central campaign message with regard to identity and Taiwanization appeared to be largely in line with the original concept of "New Taiwanese" - a Taiwan identity defined in civic rather than in ethnic terms (Rigger, 2008, p. 697). A closer analysis however, revealed that this concept was filled with a strong Taiwanese cultural underpinning, going far beyond that of previous campaigns of the KMT. Interestingly enough, the strongest emphasis on the ethnic content of the Taiwan identity could be observed during campaign rallies and in television advertisements. Clearly the goal of these election instruments was to create an emotional response from potential voters. The powerful Taiwanese undertone was further enhanced by Ma's frequent attempts to speak Taiwanese, as a key factor of ethnicity in Taiwan is the use of the language (Lee, 2005, p. 15). ${ }^{27}$ Ma also tried to connect with the grassroots during his so-called "long stay" visits, where he worked for a day with farmers, fishermen or country-side factory workers (Pearl Report, 2008). Within the concept of the "New Taiwanese", the Taiwanese culture and Hoklo language were strongly emphasized, creating a "culturally recharged" concept of "New Taiwanese" for the 2008 election campaign.

\section{CONCLUSION}

The emergence of a "culturally recharged" "New Taiwanese" can be directly attributed to the impact of two decades of Taiwanization policies by Taiwan governments. Taiwanization is a project aimed at creating identity in civic and ethnic or cultural terms. In this period Taiwanization and the definition of Taiwan identity evolved from a mainly civic-based approach to a more cultural and ethnic approach. De-Sinization under Chen Shui-bian and the election campaigns of 2000 and 2004 have forced the KMT to appear very Taiwanized so as to successfully gain mainstream support. The KMT's "New Taiwanese" concept fitted well in the earlier era of Taiwanization, but it had to be adapted to effects of the cultural policies of the Chen administration. This analysis has also highlighted the importance of discourses on culture and ethnicity for the creation of an identity. It also shows the different dimensions of Taiwan identity, which are apparent in the political and cultural spheres of Taiwanization.

In his campaign Ma Ying-jeou had to demonstrate his Taiwan identity in ethnic and civic terms; or in other words, in the political and cultural spheres framed through Taiwanization. Since the Taiwan identity is currently more culture-based than it was at the beginning of the democratization process, this forced Ma to adopt a strong Taiwanese image during the campaign. Symbols of ethnic identity were particularly present in campaign instruments that aimed at creating a positive emotional reaction in potential voters, and creating their attachment to the candidate and the party. Theoretically the case has shown that a shift towards a stronger emphasis on the ethnic component of identity is possible and can be accepted if it is perceived as an authentic development and is in concurrence with the general opinion. Nevertheless the KMT continued catering to other ethnic groups and identities besides the Taiwanese, and did uphold the "New Taiwanese" concept. Yet, the difficulties for the KMT as a catch-all party are nevertheless obvious and can be identified in the election

\footnotetext{
${ }^{27}$ The other one being the time of immigration to Taiwan, i.e. before or after 1945 (Ibid.).
} 
platform of Ma, with its inherent conflict between Taiwan identity and relations with China.

This conflict can not yet be solved by the new administration and within only a few months after his inauguration, Ma Ying-jeou has already been accused of betraying Taiwan and violating two core principles of Taiwanization - politically, the strengthening of Taiwan's sovereignty in opposition to China and focus on its democratic development; and culturally, the consolidation of Taiwan identity. In cultural terms, Ma has returned in many ways to KMT Chinese Nationalism ${ }^{28}$ by, for example publicly stating that the Republic of China includes the Chinese mainland (Ko, 2008, p. 2) and stressing Chinese ethnic and cultural heritage. ${ }^{29}$ At the same time many Taiwanese feel that he has been politically weak towards China, thus hurting the country's sovereignty ${ }^{30}$ and endangering their personal safety. They have voiced their opposition in mass protests led by the DPP in August and October $2008 .{ }^{31} \mathrm{Ma}$ reacted to the October 2008 demonstration with a statement delivered entirely in Taiwanese $^{32}$, evoking Taiwanese identity. The conflict however culminated in the large-scale protests that accompanied the visit of PRC envoy Chen Yunlin ${ }^{33}$ to Taipei in November 2008, which brought the city to a virtual standstill (Taiwan Apple Daily, November 6, 2008, p. A27). The protest of Summer and Autumn 2008 showed the strength of a Taiwan identity shaped by Taiwanization policies. Its principles have been accepted as mainstream, and have created patterns of a unique Taiwan identity, an imagined community. Many Taiwanese feel that they are politically and culturally fundamentally different from Chinese on the mainland. Ma had skillfully used ethnic Taiwan identity in the campaign to his advantage, portraying himself and the KMT as truly Taiwanese. Subsequent policies by his administration were hence seen as a surrender of Taiwanization, a betrayal of the civic and ethnic components of identity, and this was perceived as Sinization.

${ }^{28}$ In his inauguration speech he infuriated KMT aboriginal legislators by speaking of Taiwan as an "ethnic Chinese society" (China Post, May 22, 2008, p. 1), and with his sharp contrasts to the DPP's terminology of "citizen". The name changes of the Taiwan Post and the Taiwan Democracy Memorial Hall were reverted (Taiwan Times, August 22, 2008, p. 4).

${ }^{29}$ On the traditional Chinese festival, Tomb Sweeping Day (清明節), Ma Ying-jeou hosted a ceremony honoring the Yellow Emperor (皇帝), the mythical ancestor of the Chinese. It was the first time for a ROC president to host the ceremony; and the government announced that as the Yellow Emperor is the common ancestor of all Chinese people and to commemorate him, it would designate Tomb Sweeping Day as “Chinese Race Tomb Sweeping Day”. (...黃帝是中華民族的共同始祖, 政 府為紀念黃帝, 將清明節定為「民族掃墓節」). (Central News Agency, April 3, 2009). The term 民 族 can be translated as "race" or "ethnicity" and in this case, means the Chinese race or ethnicity.

${ }^{30}$ The opposition has criticised the Ma administration for being too careful not to offend China in many instances, thus endangering the island international standing. The pro-DPP English newspaper Taipei Times pointed out that KMT chairman Wu Poh-hsiung (吳伯雄) was referring to Ma Ying-jeou as 'Mister' Ma instead of President Ma, during his visit to China (Chuang, 2008, p. 1).

${ }^{31}$ The protests on 30 August 2008 and 25 October 2008 attracted 300,000 and 600,000 participants respectively, according to organizers (Lu and Chang, 2008, p. 1; Chang et al., 2008, p. 1).

${ }^{32} \mathrm{He}$ addressed the demands of the protesters during a visit to Keelung (基隆) on 26 October 2008 (Era News, October 26, 2008). Lai 2008.

${ }^{33}$ On the government's perspective on outcomes of the so-called "Chiang and Chen talks" see 
The proposed closer economic cooperation with China is likely to create more conflict as it is viewed by some sectors to further imperil the islands' sovereignty. So far Ma has always tried to evoke his ethnic Taiwanese side when pressure became too intense. It remains to be seen whether he can once again convince the public of his Taiwaneseness and balance economic realpolitik with Taiwan identity, especially with an opposition likely to focus on his stance on Taiwanization.

\section{References}

3005th General meeting of the Executive Yuan: decisions and briefing of Prime Minister (第 3005 次行政院院會決議暨院長提示). (2006, September 2). Executive Yuan announcements. Government Information Office. Retrieved October 21, 2008, from: http://info.gio.gov.tw

Allio, F. (2000). The dynamics of the identity issue in Taiwan: Understanding uniqueness, diversity and the whole. China Perspectives, 28, 43-50.

Anderson, B. R. (1983). Imagined communities: Reflections on the origin and spread of nationalism. London: Verso.

Bedford, O. \& Hwang, K. (2006). Taiwanese identity and democracy: The social psychology of Taiwan's 2004 elections. New York: Palgrave Macmillan.

Bruyas, D. (2008, February 1). Old passport clears KMT hopeful. The China Post, p. 1 .

Cabestan, J. (2005). Specificities and limits of Taiwanese nationalism. China Perspectives, 62, 32-43.

Cerulo, K. A. (1997). Identity construction: New issues, new directions. Annual Review of Sociology, 23, 385-409.

Changes in the Chinese/Taiwanese Identity of Taiwanese as Tracked in Surveys by the Election Studies Center, NCCU (1992-2007). (2008). Election Studies National Cheng-Chi University Taiwan. Retrieved October 26, 2008, from http://esc.nccu.edu.tw/eng/data/data03-2.htm

Chang, B. (2004). From Taiwanisation to De-sinification: Culture construction in Taiwan since the 1990s. China Perspectives, 56, 34-44.

Chang, M. (2000). On the origins and transformation of Taiwanese national identity. China Perspectives, 28, 51-70.

Chang, R. et al. (2008, October 26). Ralliers vent anger at Ma government. Taipei Times, p. 1.

Chao, C. \& Dickson, B. (2002). Introduction: Assessing the Lee Teng-hui legacy. In: B. Dickson and C.M. Chao (Eds.), Assessing the Lee Teng-Hui Legacy in Taiwan's Politics: Democratic Consolidation and External Relations (pp. 326). Armonk: M.E. Sharpe. 
Chu, Y. \& Lin, J. (2001). Political development in 20th-century Taiwan: Statebuilding, regime transformation and the construction of national identity. China Quarterly, 165, 102-129.

Chu, Y. (2004). Taiwan's national identity politics and the prospects of Cross-Strait relations, Asian Survey, 44 (4), 484-512.

Chuang, J. (2008, May 28). DPP condemns Wu's comments. Taipei Times, p. 1

Chuang, Y. (2001). Taiwanese identity in a global / local context: The use and abuse of national consciousness in Taiwan. In: C. Aspalter (Ed.), Understanding Modern Taiwan: Essays in Economics, Politics and Social Policy (pp. 53-65). Aldershot: Ashgate.

Corcuff, S. (2002). The symbolic dimension of democratization and the transition of national identity under Lee Teng-hui. In: S. Corcuff (Ed.), Memories of the Future: National Identity Issues and the Search for a New Taiwan. (pp. 73101). Armonk: M.E. Sharpe.

Downs, A. (1957). An economic theory of democracy. New York: Harper \& Row.

Fell, D. (2005). Party Politics in Taiwan: Party change and the democratic evolution of Taiwan, 1991-2004. Routledge: London.

Fell, D. (2006). Change and continuity in Taiwanese party politics since 2000. In: D. Fell et al (Eds.), What has changed? Taiwan before and after the change in ruling parties ( pp. 21-40). Wiesbaden: Harrassowitz.

Fell, D. (2007). Partisan issue competition in contemporary Taiwan: Is Taiwan's democracy dead? In: J. Damm and G. Schubert (Eds.), Taiwanese Identity from Domestic, Regional and Global Perspectives (pp. 23-39). Berlin: Lit Verlag.

Geertz, C. (1973).The interpretation of cultures: Selected essays. New York: Basic Books.

Gellner, E. (1983). Nations and nationalism. Oxford: Blackwell.

Ho, S. \& Liu, I. (2003). The Taiwanese/Chinese identity of the Taiwan people in the 1990s. In: W.C. Lee and T.Y. Wang (Eds.), Sayonara to the Lee Teng-hui era: politics in Taiwan, 1988-2000 (pp. 149-183). Lanham: University Press of America.

Hobsbawm, E. (1984). Introduction: Invention of traditions. In: Hobsbawm, E. and Ranger, T. (pp. 1-14). The invention of tradition. Cambridge: Cambridge University Press.

Hsiau, A. (2000). Contemporary Taiwanese cultural nationalism. London; New York: Routledge. 
Hsieh, J. F., \& Niou, E. M. S. (1996). Taiwan's March 1996 elections. Electoral Studies, 15(4), 545-550.

Hsueh, H. et al. (2005). Is Taiwan Chinese?: A history of Taiwanese nationality. Taipei: Taiwan Advocates.

Hughes, C. R. (2006). Chinese nationalism in the global era. London; New York: Routledge.

Hutchinson, J. (1987). The dynamics of cultural nationalism: The Gaelic revival and the creation of the Irish nation state. London: Allen \& Unwin in association with the London School of Economics and Political Science.

Ko, S. (2008, October 8). Ma refers to China as ROC territory in magazine interview. Taipei Times, p. 2.

Jacobs, J. B. (2005). 'Taiwanization' in Taiwan's politics. In: J. Makeham and A.C. Hsiau (Eds.), Cultural, Ethnic, and Political Nationalism in Contemporary Taiwan: Bentuhua (pp. 17-54). Houndmills; New York: Palgrave Macmillan.

Lai, S. (2008, November 7). Outcome and explanation of the $2^{\text {nd }}$ "Chiang - Chen talks". Mainland Affairs Council. Retrieved March 10, 2009, from http://www.mac.gov.tw/english/english/cc2/971107.pdf

Lee, W. \& Wang, T. (Eds.). (2003). Sayonara to the Lee Teng-hui era: Politics in Taiwan, 1988-2000. Lanham: University Press of America.

Lee, W. (2005). Taiwan's cultural reconstruction movement: identity politics and collective action since 2000. Issues and Studies, 41(1), 1-51.

Li, Z. (2007, May 21). Is the old Chiang [Chiang Kai-shek] asset or debt? (老蔣是資 產還是負債?). United Daily News, p. A15.

Lin, C. (2002). The political formation of Taiwanese nationalism. In: S. Corcuff (Ed.), Memories of the Future: National Identity Issues and the Search for a New Taiwan (pp. 219-241). Armonk: M.E. Sharpe.

Liu, M. et al. (2005). Identity issues in Taiwan's history curriculum. In: E. Vickers and A. Jones (Eds.), History education and national identity in East Asia (pp. 201-132) London, New York: Routledge.

Llobera, J. R. (2004). Foundations of national identity: From Catalonia to Europe. New York: Berghahn Books.

Lu, M. \& Chang, R. (2008, August 31). Rally targets Ma on $100^{\text {th }}$ day in office. Taipei Times, p. 1.

Ma Ying-jeou addresses demonstrators. (2008, October 26). Live broadcast. Era News (年代新聞). 
Ma attended the first televised platform presentations for Presidential Candidates. (2008, March 3). Kuomintang News. Retrieved October 10, 2008, from: www.kuomintangnews.org

Ma receives Chen today, the Greens [DPP and supporters] call 100.000 to encircle the city (馬今接見陳 綠召 10 萬人圍城). (2008, November 8). Taiwan Apple Daily, p. A27.

Ma Ying-jeou Statement. (2008, March 18). Kuomintang News. Retrieved March 19, 2008, from: www.kuomintangnews.org

Ma, Y. \& Siew, V. (2008a). Human rights policies (馬英九、蕭萬長人權政策). MaSiew Election Platform. Retrieved April 29, 2008, from: http://www.ma19.net/

Ma, Y. \& Siew, V. (2008b). Constitutionalism reform policies (馬英九、蕭萬長憲政 改革政策). Ma-Siew Election Platform. Retrieved April 29, 2008, from: http://www.ma19.net/

Ma, Y. \& Siew, V. (2008c). Cultural policies (馬英九、蕭萬長文化政策). Ma-Siew Election Platform. Retrieved April 29, 2008, from: http://www.ma19.net/

Muyard, F. (2008). Taiwan Elections 2008: Ma Ying-jeou's victory and the KMT's return to power. China Perspectives, 2008/1, 79-94.

Nathan, A. J. (1993). The Legislative Yuan elections in Taiwan: Consequences of the electoral system. Asian Survey, 33(4), 424-438.

Pan, I. (2000). 'Pingpu' consciousness in today's Taiwan. China Perspectives, 28, $82-88$.

Philips, S. (2007). Between assimilation and independence: Taiwanese political aspirations under Nationalist Chinese rule, 1945-1948. In: M. Rubinstein (Ed.), Taiwan: A new history (expanded ed) (pp. 275-319). Armonk: M.E. Sharpe.

President presides over ceremonies at Yellow Emperor tomb for first time after change of government (總統主持黃帝陵遙祭 政府遷台後第一次). (2009, April 3). Central News Agency. Retrieved April 12, 2009, from: www.gov.tw

Rigger, S. (2008). Taiwan's Presidential and Legislative Elections. Orbis, $52(4), 689-700$.

Schafferer, C. (2006). Electoral campaigning in Taiwan. In: C. Schafferer (Ed.), Election campaigning in East and Southeast Asia: Globalization (pp. 29-54). Aldershot: Ashgate.

Schubert, G. (1999). A new rising nation? The discourse on national identity in contemporary Taiwan. China Perspectives, 23, 54-64. 
Schubert, G. (2004). Taiwan's political parties and national identity: The rise of an overarching consensus. Asian Survey, 44(4), 534-554.

Schubert, G. (2006). Towards the end of a long journey: Assessing the debate on Taiwanese nationalism and national identity in the democratic era. Asien, 98, 26-44.

Schubert, G. \& Braig, S. (2007). How to face a rising China? The DPP's identity politics and cross-strait relations at the end of the Chen Shui-bian era. In: J. Damm and G. Schubert (Eds.), Taiwanese Identity from Domestic, Regional and Global Perspective. (pp. 7-22). Berlin: Lit Verlag.

Shan, S. et al. (2007, February 13). Postal service, oil refiner change names. Taipei Times, p. 1.

Shulman, S. (2002). Challenging the civic/ethnic and west/east dichotomies in the study of nationalism. Comparative Political Studies, 35. 554-585.

Smith, A. D. (1991). National identity. Reno: University of Nevada Press.

Taiwan Democracy Memorial Hall becomes history - inscriptions subject to public consultation (民主紀念館走入歷史 骗額訴諸公民表). (2008, August 22). Taiwan Times, p.4.

Taiwan's Renaissance: President Ma's Inaugural Address. (2008, May 21). China Post, p. 1.

Taiwan democracy memorial hall becomes history - inscriptions subject to public consultation (民主紀念館走入歷史 匾額訴諸公民表). (2008, August 22). Taiwan Times, p. 4.

The Pearl Report. (2008, March 25). Taiwan presidential elections. Hong Kong: TVB Pearl.

Tsai, S. H. (2005). Lee Teng-hui and Taiwan's quest for identity. New York: Palgrave Macmillan.

Wachman, A. (1994). Taiwan: National identity and democratization. Armonk, N.Y: M.E. Sharpe.

Wong, B. W. K. (2004). Localisation in the 2004 presidential election campaign in Taiwan: An iconographic approach. China Perspectives, 55, 49-56. 